\title{
Issues of increasing the effectiveness of beet and rawsugar subcomplexes in terms of environmental protection
}

\author{
IvanSaltyk ${ }^{1}$, LyudmilaMalysheva ${ }^{1}$, OlgaTsukanova $^{2}$, and Galina Karpova ${ }^{2}$ \\ ${ }^{1}$ Kursk State Agricultural Academy named after professor I. I. Ivanov, 70, Karla Marxa st., Kursk, Russia \\ ${ }^{2}$ Southwest State University, 94, 50 Let Oktyabrya st., Kursk, Russia
}

\begin{abstract}
The article discusses the issues of increasing the effectiveness of the functioning of beet and raw sugar subcomplexes in terms of environmental protection. The main areas of scientific and technical progress aimed at increasing the profitability of the production of sugar beets, sugar cane and sugar as a final product at these subcomplexes as well as reducing harmful effects of their growing andproduction processeson the atmosphere, soil, and water bodies have been identified. The authors consider the development of new product lines and machines in accordance with the system of machines for sugar factories, modernization of existing and development of new trailed beet and cane harvesting machines; resource saving: intensification of the use and processing of beet and cane raw materials, ensuring a minimum amount of waste and its comprehensive processing; problems of greening associated with the work of sugar factories.
\end{abstract}

\section{Introduction}

Sugarcane and sugar beet are two sugar crops grown in many countries around the world for the production of a sweet product - sugar. For example, in Pakistan, sugar cane is the main raw material for the production of white sugar although sugar beets are also grown there. In this country, sugar cane is cultivated on an area of nearly 1 million hectares with a gross yield of 44.6 million tons and an average yield of 48.8 tons/ha [1].

Sugar as a high-calorie carbohydrate-containing food product (the energy value of $100 \mathrm{~g}$ of granulated sugar is $379 \mathrm{kcal}$ with a carbohydrate content of $99.8-99.9 \mathrm{~g}$ ) is used both in a pure form and as a raw material in bakery, confectionery, canning, food concentrate and others industries in many countries. This product is widely used by the population for home cooking of fruit and berries. Havinga high calorie content and the ability to long-term storage under appropriate conditions practically without losses, sugar plays an important role in the formation of state food reserves [2].

In Russia, only sugar beets are grown for sugar production. It is the most important industrial crop, the main source of raw materials for the sugar industry. One beet hectare of crops with a yield of 300-500 centners provides an average yield of 45-70 centners of sugar, 4560 centners of by-products in terms of feed units; from each ton of raw beets, $120-150 \mathrm{~kg}$ of sugar are produced. Long-term experience in the production of this crop shows that the presence of sugar beet in the crop rotation leads to an improvement in the efficiency of agriculture, an increase in land productivity, improvement of the use of the rural labour resources, and increase of the profitability of farms. The introduction of the required amount of fertilizers, perfect autumn tillage, weed control throughout the growing season create favourable conditions for the growth and development of subsequent crops [3].

Weed controlis one of the most important and expensive elements of sugar beet production. Experimental field tests on the use of glyphosate in weed control,conducted in Germany and Poland in 2010-2011, have shown its high efficacy. Compared with traditional methods of control, it not only reduced the amount of herbicides used but also significantly reduced the dosage of active ingredients. In glyphosate-resistant sugar beets treated with glyphosate herbicide, the yield of white sugar increased up to $18 \%$, which was an undeniable advantage compared to conventional herbicide systems with high application rates [4].

However, in the $21^{\text {st }}$ century, due to the intensive development of industrial and agricultural production around the world, environmental problems have become urgent, and the reduction of technogenic impact on the environment is turning into a strategic direction for the development of the world community. This is also due to the fact that in many countries, over the past decade the volume of beet processing at sugar factories has increased, which indicates the possibility of a serious aggravation of environmental problems in the sugar and beet industries in the near future.

This will also be facilitated by the growth in the cost of using natural resources, especially water and soil. There are many sources of environmental pollution at

\footnotetext{
Corresponding author: m.1.w.71@mail.ru
} 
'sweet'enterprises; they include the main production using a large amount of water of different categories, the work of the lime and gas units, the pulp drying units, thermal power plants, etc. Soil contamination in beetgrowing farms can be caused bynon-compliance with the technology (timing, methods, doses) and fertilization techniques, the use of components for regulating the soil reaction, plant protection, poor quality of the applied means, disturbance of the soil cultivation system, causing deterioration of its structure, negatively affecting the microflora [5].

\section{Materials and methods}

The theoretical and methodological basis of the study includes the provisions of classical economic theory, the works of Russian and foreign scientists in the field of agriculture-based economy, the regulatory legal acts of the Russian Federation on the functioning of the agroindustrial complex and the agri-food market. The work is based on a system approach and the method of dialectical cognition, which make it possible to consider the development patterns and processes in interrelation and interdependence.The study was conducted applying a number of general scientific methods and specific techniques (economic, mathematical and statistical) as well as analysis of literary sources.

\section{Results and discussion}

Unfortunately, glyphosate, which was discussed above, despite all its advantages, is one of the soil pollutants. So, what exactly is glyphosate? It is a nonselective systemic herbicide used to control weeds, especially perennial ones. Its production takes the first place among herbicides in the world. The active substance of the product is produced under such trade names as Roundup, Vikhr', Hurricane-Forte, Ground, Tornado, Argument Star, Triumph, Ampir, Agrokiller, Rubit-SANTI, ZARIT, etc. According to a number of studies, it is dangerous to humans.

For the first time, the herbicidal properties of this substance were discovered by John Franz, who worked for the American company Monsanto. In Monsanto, John Franz was mainly engaged in the synthesis of new organic substances; then he investigated the processes of creating polymers. In 1970, synthesizing new substances, John Franz tried to create related substances with stronger herbicidal properties. The third compound synthesized by Franz was glyphosate which turned out to be a very powerful systemic herbicide.

The trade name for glyphosate is Roundup, means a circle of wagons that caused American settlers to shoot back at Indians. Its action is due to the fact that when entering the plant cells, it blocks the synthesis of a number of compounds necessary for it, and the plant dies [6].

In March 2015, the International Agency for Research on Cancer of the World Health Organization, based on the published data from epidemiological and experimental studies, released a conclusion that glyphosate is a possible carcinogen for humans [7].

It also revealed the ability of glyphosate to damage DNA and cause chromosome aberrations in human and animal cells cultivated in vitro. It was found that spraying glyphosate-containing herbicides near humans increased the frequency of chromosomal damage (micronuclei) in blood cells [8]. In addition, there are observations that glyphosate causes cancer in laboratory rats and mice [9].

At the turn of the $20^{\text {th }}-21^{\text {st }}$ centuries, in the hilly area ofthe western part of the Slovak Republic, the influence of various forms and doses of nitrogen fertilization on the quantitative and qualitative parameters of sugar beet was studied in order to develop environmentally friendly methods of growing this crop. So, in particular, it was found that the production parameters of the 'sweet crop' in the crop rotation "alfalfa - winter wheat - sugar beet" on fertile chernozems (black soil) in an extremely arid climatic region strongly depended on the amount of nitrogen supplied to the soil. It is of interestthat with a decrease in its application to soil together with mineral fertilizers, the quality parameters of sugar beet significantly increased and at the same time, the risk of soil and nearby water bodies contamination with nitrates decreased [10].

In turn, the negative environmental situation influences the quality of sugar beet crop, in particular its tops, which are fodder for farm animals causing deterioration of the quality of livestock products and, at the end of the chain, of the quality of food.

Thus, the ecological problem in the sugar beet subcomplex turns into a problem of human life safety. Therefore, the issues of increasing the efficiency of the functioning of a sugar beet subcomplex should be considered in the context of the problems of environmental protection.

In the $21^{\text {st }}$ century, environmental problems of production are becoming so urgent that the creation of waste-free and low-waste technologies in many countries are considered as a strategic direction for the rational use of natural resources and environmental protection. This is all the more important since the production processes of sugar and starch-syrup factories have an adverse effect on the environment.

The level of atmospheric gas pollution by emissions of harmful substances (carbon monoxide, nitrogen oxides, sulfur dioxide, ammonia) exceeds the maximum permissible concentrations, production wastewater contains a significant amount of organic substances, their purification in natural conditions is associated with certain difficulties and requires significant land areas.

In recent years, the issues of using green and renewable energy sources have been actively solved in the economies of various countries $[11,12,13]$.

This type of energy includes ethanol, which can be obtained from sugar beets and is used instead of (or mixed with) fossil fuels to reduce environmental pollution. The latter circumstance has led to a sharp increase in ethanol production. Analysis of its production reveals that $39 \%$ of ethanol was produced from agricultural products containing sugar and molasses, 
$48 \%$ - from corn, $10 \%$ - from biomass and only $3 \%$ was obtained from chemical synthesis. According to [14], for the production of 76 million liters of ethanol per year, provided that 90 liters of ethanol are produced from $1,000 \mathrm{~kg}$ of sugar beets (with a sugar content of about $17 \%$ ), about 840 thousand tons of beets are needed. And the necessary investments to start up a plant for bioethanol production are about 119 million dollars, which is cost-efficient. Ethanol production not only helps to reduce environmental pollution but can also be a source of income for rural producers, processing enterprises and the economy of the country as a whole.

In recent decades, many countries of the world have taken a number of structural and organizational measures aimed at increasing the efficiency of beet and cane sugar production, and reducing environmental pollution caused by the related processes [14].

Thus, the experience of the 2006 sugar reform carried out in the European Union is of importance; it affected the sugar industry in many European countries. As a result, the production of sugar beet and white sugar was significantly reduced, and many production facilities were closed down. The number of sugar factories has decreased by more than $50 \%$, and the number of people engaged in sugar industry has also significantly decreased (about $50 \%$ ). Sugar factories with outdated technological equipment, which were ineffective and had an adverse impact on the environment, were closed firstly. During the sugar reform, the competitiveness of those sugar and sugar beet producers who were able to survive increased. The reform strengthened the position of the main producers and eliminated many of their competitors [15].

Many long-standing problems have accumulated in the cane and sugar industry of the Republic of Bangladesh. In this country, the percentage of sugar extracted from sugar cane in research stations is very different from that in sugar factories. Thus, in the period from 1971 to 2006 , the latter had on average only $7.57 \%$ of sugar extraction. While the break-even analysis of the functioning of the country's sugar industry showed that to ensure the economic viability of the industry, this indicator must be at least $8.91 \%$.

A low percentage of sugar extraction from cane, and, accordingly, its yield per hectare, high losses of sweet product during processing, weak utilization of production capacities of processing enterprises, postharvest losses of harvested raw materials on pile fields and ineffective management of the cane-sugar industry are the main reasons for the low efficiency of sugar industry in Bangladesh. This also has a negative impact of the industry on the environment [16].

The attempts to carry out thereform of the 'sweet' industry are also being made in Thailand. The need for reform was caused by the issues of raising wages in agricultural sectors, a shortage of cane workers, and the inability of industry top managers to expand the cultivated area in the East and West regions of this country. These problems led to the relocation of many sugar factories from the disadvantaged regions to the northeastern, lower northern and central regions of
Thailand.Let us note that this decision is consistent with the country's official government policy to allow relocation and expansion of processing facilities.

In the near future, more machines for cutting and loading cane will be used in Thailand to replace hard physicallabour. An increase in the degree of mechanization of labor-intensive processes in the cultivation and processing of cane should also reduce the negative load on the environment [17].

Thus, the industrial ecology of sugar production in many countries of the world remains an extremely urgent problem. The technogenic impact of the enterprises of the industry has the most negative effect on water resources, since in terms of water consumption per unit of output; the beet-sugar industry takes one of the first places among the industries of the economies of sugarproducing countries.

When reconstructingthe existing and building new factories, measures aimed at protecting surface and underground waters from pollution and depletion, reducing the consumption of river and artesian water for technological needs, reducing the area of agricultural land alienated for filtration fields are envisaged. Wastewater from factories is recycled.

The deterioration of the ecological situation and the increase in the contamination of food with radionuclides, toxic chemical compounds, biological agents have a negative impact on the health of the population. In this regard, the task of the world science is to create products of a new generation with high nutritional and biological value.

So, the industrial ecology of sugar production remains an urgent problem. The technogenic impact of the enterprises of the sugar industry has the most negative effect on water resources, since in terms of water consumption per unit of output, the beet-sugar industry takes one of the first places among the industries of the economies of sugar-producing countries. In this regard, it is necessary to implement new schemes for recycling water supply, which will allow minimizing the use of fresh water in the production cycle and wastewater discharge.

Thus, summarizing the above, we can make a conclusion concerning the main environmental problems of beet and raw sugar production:

- high-volume of fresh water consumption;

- large amount of generated wastewater and unused waste, requiring significant energy consumption for pumping them to filtration fields, and the associated high risk of contamination of open water bodies in the event of a disruption in the operation of treatment facilities;

- large amount of unused waste;

- removal of significant land areas for filtration fields and dumps from economic circulation;

- removal of a fertile layer of soil from agricultural fields;

- pollution of water bodies with industrial waste;

- air pollution with dust, carbon dioxide and other harmful gases.

The implementation of these and other technical and organizational measures will reduce harmful emissions 
into the atmosphere and wastewater discharges to a level below the maximum permissible concentrations.

As the research data show, similar to many other sugar-producing countries, the Russian sugar beet subcomplexhas all the prerequisites to raise the production and processing of sugar beets and sugar cane to a higher level. Moreover, now there is an urgent need not only to overcomethe economic crisis through modernization of the material and technical base of beet and raw sugar subcomplexes but to set fundamentally new tasks in raising the technical level of sugar production. For the Russian sugar beet subcomplex, the main tasks include the solution of a number of purely technical problems, consisting in:

- increasing the coefficient of extraction of sugar from beets to $0.82-0.85 \%$ by reducing its losses in the process of production to $0.70-0.75 \%$ and content in molasses to $1.5-1.6 \%$ by weight of beets;

- reducing the consumption of fuel equivalent to 3.5$4.0 \%$ by weight of beets;

- reducing the consumption of limestone for technological needs up to $4.5-5.0 \%$ to the mass of processed beets;
- labour costs for processing 100 tons of beets equal to no more than 3 hours [19].

The European standard for sugar quality should also become the standard for Russian factories.

It is obvious that the sequence and scope of work on the technical re-equipment and reconstruction of sugar factories directly depend on the understanding of these problems by their owners - commercial and industrial companies. However, only a few of them have started implementation of large-scale programs for the technical re-equipment of their factories, developed based on the results of a comprehensive survey (technical audit) of the enterprises.

A decrease in the production of sugar beets and sugar cane and, accordingly, the production of sugar from them may also occur due to a shortage of basic resources necessary for their cultivation (equipment, fuel and lubricants, mineral fertilizers and herbicides), which may arise due to a significant difference in prices for these resources and products manufactured by agricultural enterprises. The priority directions of scientific and technological progress in the beet-sugar and raw-sugar subcomplexes are shown in Figure 1.

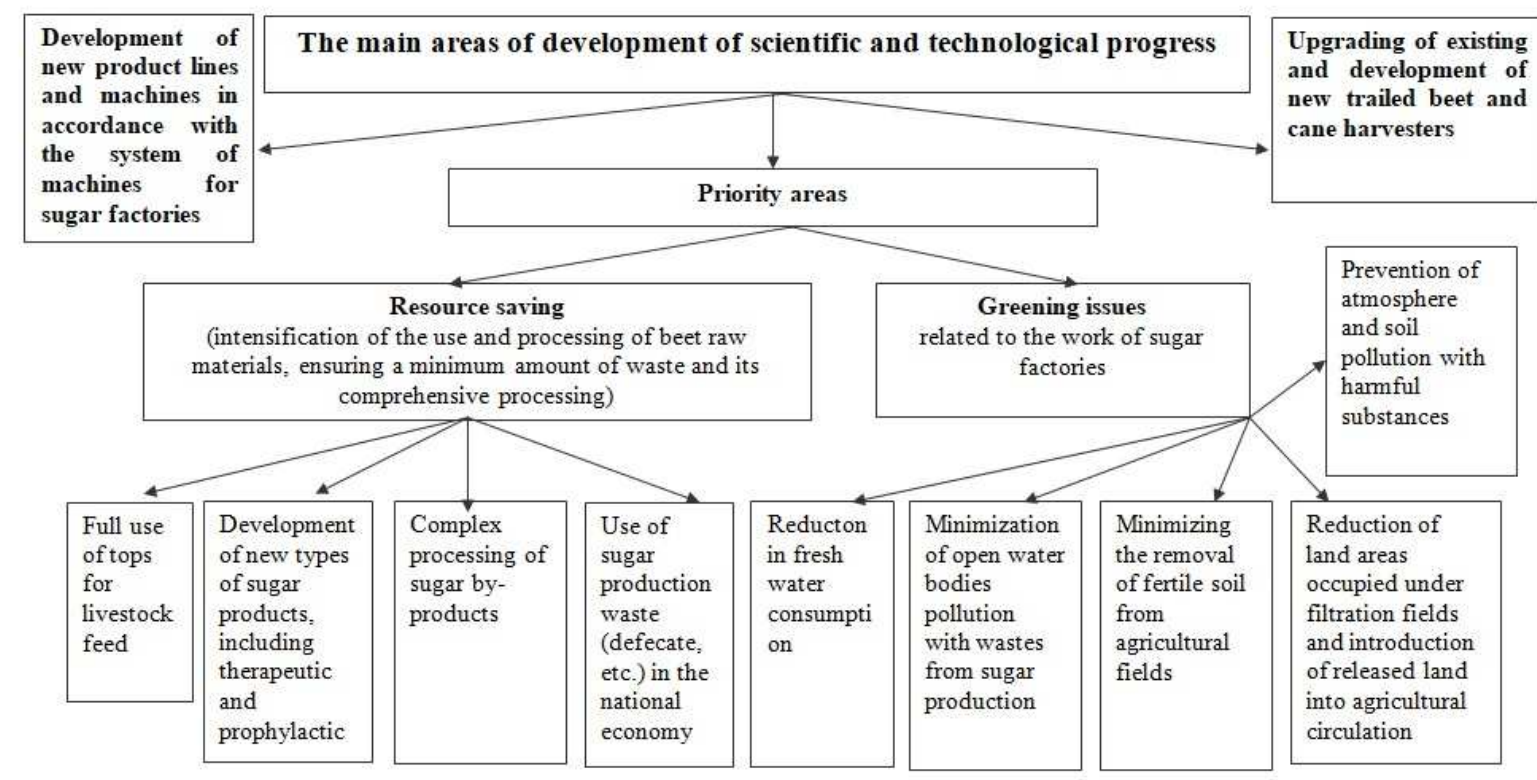

Figure 1.Main areas of scientific and technological progress in the beet and raw sugar sub-complexes in the context of environmental protection [18]

\section{Conclusion}

In the scientific discussion, it was revealed that in order to solve the problems of increasing the efficiency of the functioning of beet and raw sugar subcomplexes in the context of the problem of environmental protection, it is necessary to use the developments of scientists. Scientific and technical progress in these subcomplexes should be aimed at the development of new product lines and machines in accordance with the system of machines for sugar factories; modernization of existing and development of new trailed beet and cane harvesting machines; resource conservation, aimed at intensifying the use and processing of beet and cane raw materials. This would ensure a minimum amount of waste and its comprehensive processing; the problem of greening associated with the work of sugar factories.

Thus, in order to achieve world-class indicators of intensification of sugar production, Russia and other countries need to sharply raise the technical level of sugar factories, carry out their technical re-equipment and reconstruction, and find investors for these purposes. Transformations in sugar production, in our opinion, should be associated primarily with an increase in the efficiency of its functioning by attracting investments for the modernization of production based on modern achievements of scientific 
and technological progress. As the practices of Russia, the Republic of Bangladesh and the beet-growing countries of the European Union show, bringing the beet- and raw-sugar subcomplexes to a new technical level is a capital-intensive task. It can be solved only during many years of purposeful work within the framework of a unified program for the technical reequipment of sugar enterprises, balanced with the program for the development of their raw material areas.

A significant role in this area is assigned to science. However, the further development of scientific and technological progress in the beet and raw sugar subcomplexes should be linked to the solution of environmental protection problems.

\section{References}

1. M.A. Majid, Pak. SugarJ. 22, 2-21, (2007)

2. V. D. Goncharov, A. N. Kuropatkin Sugar Industry 2, 2-6,(1997).

3. A. T. Kalinin, A. A. Kalinin Sugar beet 7,5-7, (2002)

4. H. Nichterlein, A. Matzk, L. Kordas, J. Kraus, C. Stibbe Transgenic Research. 22(4), 725736,(2013)

5. F. Khitskov (Ed.) The system of conducting agro-industrial production in the Voronezh region until 2010 (Voronezh: Publishing house "Centre for Spiritual Revival of the Black Soil Region”, 2005).

6. Glyphosate Retrieved from: https://ru.wikipedia.org/wiki/Glyphosate

7. Z.Guyton Kathryn, Loomis Dana, Grosse Yann, El Ghissassi, Fatiha Benbrahim-Tallaa, Lamia Guha, Scoccianti Chiara, Mattock Heidi, Straif Kurt. The Lancet: journal. 16(5), 490491,(2015)

8. International Agency for Research on Cancer, World Health Organization Monographs Volume 112: evaluation of five organophosphate insecticides and herbicides. Retrieved from: https://www.iarc.who.int/wpcontent/uploads/2018/07/MonographVolume11 2.pdf

9. D. Cressey, Nature.(2015).

10. Š. Žák, M. Macák, K. Kováč, 2006 Energy balance of potato growing in ecological, lowinput and conventional production systemRetrieved from: https://agris.fao.org/agrissearch/search.do?recordID=SK2007000099

11. Fan Hua, Li Yangyang, Fei Cong, HuoPeishu, Wang Kaiyong Sugar Tech, 18, 309-316,(2016)

12. Cano R., Nielfa A, Fdz-Polanco M,Bioresource technology, 168, 14-22,(2014).

13. Siddhartha Pal, Shereena Joy, Kalpana D. Trimukhe, Pramod S. Kumbhar, Anjani J. Varma, and Sasisanker Padmanabhan. Biotech. 6(2) 126 (2016)
14. B. Babaee, M. abdollahianNoghabi, P. Norozi, H. Noshad, et al. Feasibility of producing bioethanol from sugar beet Retrieved from:https://agris.fao.org/agrissearch/search.do?recordID=IR2015001562

15. L. Smutka, Cukrovarnicke in Reparské. 129 (1), 22-27, (2013)

16. M.M. Alam, G.M.M. Alam, M.A.S. Miah, S.M.K. Rahman Factors affecting sugar recovery of Bangladesh sugar industry Retrieved from: https://agris.fao.org/agrissearch/search.do?recordID=PK2009000647

17. Amman Sayamwala, Prayong Netyarak, Worawut Hiranrak, Thai cane and sugar industry in future Retrieved from:https://agris.fao.org/agrissearch/search.do? recordID=TH1999002095

18. I.P. Saltyk, Economic problems of functioning of a beet sugar subcomplex as a part of an agroindustrial complex: by data of Central Black Earth region (Moscow: Nauka, 2009).

19. V. M. Severin Sugar beet 11, 2-4, (1999) 